\title{
N-Glycosylation Site
}

National Cancer Institute

\section{Source}

National Cancer Institute. N-Glycosylation Site. NCI Thesaurus. Code C14051.

A glycosylation site is an amino acid residue within a peptide that accepts oligosaccharide via amide linkage, specifically through amide nitrogen of asparag ine via $\mathrm{N}$ acetylglucosamine, as one of the post-translational modifications. 